\title{
INNOVATING SCIENCE STUDENT-TEACHER'S PRACTICUM IN NIGERIA
}

\author{
Jacinta A. Opara \\ Center for Environmental Education, Universidad Azteca \\ Chalco-Mexico \\ E-mail address: nkasiobisilasoguzor@yahoo.com
}

Keywords: innovating science; student-teacher's; Nigeria

\begin{abstract}
The training of the science teacher requires both theory and practice. Teaching practice refers to a period of guided teaching during which the teacher-trainee or student-teacher assumes increasing responsibilities for directing the learning of a group of students over a period of some weeks, (about 12 weeks in all). Within this period, the student teacher undergoes a periodical apprenticeship under the guidance of supervisors from the training institutions and the co-operating school harboring the student teacher. In the process they endeavour to marry the theory taught and learnt with practice. The processes help them to acquire the necessary new skills, insights, attitudes and responsibilities which are basic to the teaching career/profession.
\end{abstract}

\section{INTRODUCTION}

Science teaching is a systematic activity deliberately engaged in by somebody to facilitate the learning of the intended worthwhile scientific knowledge, skills and values by another person and getting the necessary feedbacks. This calls for good knowledge of four criteria of teaching.

- Teaching is a systematic activity that requires planning and the use of appropriate methods. Classroom practices result from planning decision on what and how to teach, and the person to be taught. The teacher should always consider the level of intellectual and physical maturity of the students who are the learners before deciding on the most appropriate method.

- Teaching is all about somebody (teacher) making it possible for somebody else (learner) to learn something. Teaching is external to the leaner, being done by another person the teacher.

- Teaching is objective based exercise. This is because it involves something to be learnt. It is intentional behavior which has clear goals.

- Teaching involves the continuous assessment of the student's behavior. Feedback regarding the extent which objectives of teaching are achieved can adequately being obtained through effective monitoring alone.

- Teaching is a good attempt to assist and guide the learner to acquire or change an attitude, knowledge, idea, skill or appreciation. Teaching consists essentially of setting of the stage for qualitative learning. Setting of the stage demand that the teacher should be capable of influencing desirable changes in the behavior of the learners. The teacher should create enabling environment and opportunities for the students to interact with materials so that he/she can learn since students learn more by doing, they should be actively and totally be involved in learning situations as a means of enhancing learning. Actual classroom teaching practices are so varied, so complex, so fluid as to almost to give any exact description.

\section{CONCEPT OF SCIENCE TEACHING PRACTICE}

Teaching practice amongst science-teachers has been recognized as a very important component in the professional education of science teachers. Its supervision equally has been a source of concern to many teacher educationists and educators. During teaching practice the 
supervisor observes the student-teacher teaching a group of students after which the supervisor gives the student teacher some feedback. The major aim is solely to improve teaching and learning. Effective science teaching is challenged by some of the problems associated with the exercise such includes:

The seriousness and relevance of teaching practice as an integral component of teacher preparation toward quality teaching and learning for effective and efficient natural educational system has called for need for evaluation of the student - teachers. For this reason, evaluation procedures appear somehow similar in the universities in Nigeria. The steps involved are

1. Appointment of supervisors to the student - teachers: during the teaching practice the supervisors are appointed by the department in some cases by the college or faculty of the student - teachers. It is always recommended that a more than a supervisor should supervise a student teacher. It also recommended that adequate number of times for the supervision should be minimum of two and maximum of three of which the average is taken as the score. The essence is to remove traces of bias from the supervisors and the fact that one shot examination is not a true test and picture of one's ability. It also proves a good forum for effecting corrections to a feedback previous supervision.

2. Appointment of secondary supervisors: these secondary supervisors are usually the principal and teachers of the cooperating schools. These cooperating teachers are assumed professionals in the field. They are expected to serve as models and source of the actual practical and practice. They should directly take these students teachers round all the expected tasks. They should make more concrete and appropriate report on the all-round assessment of these supervisees.

3. Provision of evaluation form: The evaluation is never oral exercise. It must be written and documented electronically, or hardcopy. For this reason, there are a variety of evaluation formulas in use by this institution. They generally contain essentially the same items sought by teacher's preparation institution. These must be made available to the supervisors, cooperating principals and teachers. They must be educated on the effective use. Essential elements being considered include:

- Personal qualities, preparation and presentation of lesson, professional qualities, techniques of teaching

- Ability to plan for instruction, and generate factors

- Class management

- Competency in guiding experiences or learners.

- Class activities and evaluation techniques

- Effective participation in the school activities etc.

- The students teachers need to be cognizant of the expectations and probable interpretations of his/her performance

A cooperate approach is necessitated as the cooperating teachers and the supervisors make judgment about the students, progress. It is very crucial to communicate these judgments clearly to the students-teachers so that there is a mutual understanding of the bases upon which they are prepared.

Rating: In many of these educational institutions, rating scales of various kinds are available. They are used in recording judgments about the supervisees, teachers progress based on letter - rating system of A, B, C, D, E and F. The mark allotted is based on the Conesus of the supervisors who did the supervision and at such are very familiar with the work done by the students - teachers during the teaching practice. It is always good that he training institution supervisors take into consideration the cooperating teacher's assessment of the students teachers before assigning the final score and grade. It is worth noting that up till this year 2013, that there are still disagreements among the educators themselves and various institutions as to the effective and suitability of some of the rating forms being used. It has been observed that many institutions have been trying different forms with a view to finding a more suitable one. Institute of education of University of Nigeria for example, has adopted a new form which seems to be modification of the one being used by the Department of education of the same faculty. Other institutions faced and are still facing 
these challenges. The present evaluation form will continue to be reviewed by educator's educationists and educational administrators until a more standardized performs acceptable for minimum standard uniformity is produced. That notwithstanding there is need for regular standardization of teaching practices evaluation proforms for adaptability and results - oriented to a changing society.

\section{ISSUES IN SCIENCE TEACHING PRACTICE EVALUATION PROFORMA}

1. There exist some inherent difficulties in the use or application of rating scales to be recognized.

2. Some of the items demand subjective judgments observation has shown that most times that supervisors find it very difficult to assign a score on such an item as "Language and voice control"

This is simply because different people have different "tones" while speaking and as such what may be considered a "coaxing voice" to one supervisor may be a "soothing voice" to another for standardization to be maintained, each supervisor using the device must give it similar interpretation under the circumstance.

3. There is a seemingly lack of agreement in the teaching profession on the actual purposes of student teaching practice.

4. There is seemingly lack of agreement on the adequate duration of teaching practice.

5. Lack of agreement on qualities and competences of good teacher.

6. Lack of agreement on how to rate the different items.

7. Lack of agreement on who should determine the final grade of the student teacher.

\section{SCIENCE TEACHING PRACTICE CURRICULUM PROVISION EVALUATION RELEVANCE}

Curriculum is the totality of learning experiences that a student teacher must be exposed to before and within the teaching practice practicum under the guidance of the education institution. The teacher education curriculum must be in line with programmes. Teacher education curriculum is the teaching and learning activities or experiences provided by a teacher education institution within and out of its geographical location for the purpose of equipping teacher trainee (studentteachers) with the needed skills and competences required to work in the educational field. These activities or experiences could be academic, non-academic, vocational, technical, emotional and ethical which must be planned and guided by the training institution. The Federal Republic of Nigeria stated that these learning experiences or curriculum of teacher education will be structured to reflect the following components:

- General studies (Basic Academic Subjects)

- Foundation studies (Principles and Practice of Education)

- Studies related to the students' intended field of teaching (Example: English, Mathematics, Biology, Chemistry, Physics, Geography, History etc) and

- Teaching practice

Effective teaching is challenged by some of the problems associated with the exercise such includes:

\section{SCIENCE TEACHING PRACTICE CURRICULUM PROVISION CHALLENGES}

Teaching practice is allowed the shortest possible period of time in the teacher preparation programme.

- Limited time, if it all is given to the seminars run as part of teaching practice and used to share field experiences, develop or reinforce specific teaching concepts.

- There is a pressure of larger numbers of students to be accommodated in Teaching Practice than educational institutions can efficiently and effectively managed without strain on its staff. 
- Supervising teachers in the cooperating schools are not usually involved in the teaching practice seminars.

- Teaching practice is also conducted amidst of lecture and farm practice.

- Experience has always shown that teaching practice is not adequately evaluated in most institution.

- Inadequate motivation for the supervising staff, transport and financial constraints contribute greatly in lowering quality teaching practice.

- Large number of student teachers usually assigned to each staff makes supervision difficult for the assessment to be adequately or properly conducted.

\section{SCIENCE CURRICULUM AND THE STUDENT TEACHER}

Curriculum can be defined in varied ways, depending on the authors and authorities perceptions.

1. Curriculum is generally seen as the subjects included in a course of study or taught at a particular school.

2. It is ground which learners and teachers must cover in order to reach the goals/objectives of education

3. It is a planned experiences offered to the learner under the guidance of the school

4. Logically connected set of conceptually and pedagogically analyzed knowledge and value claims.

Curriculum therefore specifies the objectives, learning experiences, contents, methods, instructional materials and evaluation techniques of a learning task. Overall objectives, are stated in a behavioral terms. There must be link and topic, objectives, contents, activities, instructional materials and evaluation. It guides the teacher drawing scheme, lesson note, lesson delivery etc.

\section{SCIENCE CURRICULUM PROCESS}

This refers to the process of

- determining the needs/aspiration of the society to be served

- selecting metering content of the subject matter

- the organization of the content and learning experiences

- evaluating the outcomes of any activity in relation to the objectives/needs/aspirations mapped out for it.

\section{SCIENCE CURRICULUM MATERIALS}

This refers to all instructional or resources that help the teacher and the student achieve effective teaching and learning. They are classified as

- Projected aid: Opaque, micro, overhead, film slides projectors.

- Two-dimensional aid: Maps, atlas, time charts, pictures, diagrams, walk charts.

- Three-dimensional aids: Templates, specimens, dioramas, models etc.

Major Qualities of Good Science Curriculum Materials

The major characteristics indicate that good curriculum materials must possess elements of

- Relevance

- Durability

- Clarity

- Appropriateness

- Specificity

\section{Science Curriculum Design}

- Core-curriculum,

- Subject-curriculum

- Learner (child/student) centered curriculum 


\section{Sources of Science curriculum/educational objectives:}

- The societal needs

- The national philosophy

- The learner and

- The subject matter specialist

\section{Scheme of Work}

It is breakdown of the syllabus into weekly schedule of work to be done in each class in each subject.

\section{Functions of Scheme}

1. It enables revision to be taken at regular intervals, showing progress made and weak points to be amended.

2. It provides satisfaction that efficient work is being done.

3. Scheme that is carefully and logically arranged allows thorough teaching of each lesson necessarily on time available with adequate preparation.

4. Habits of being attentive are formed as the students find something worthwhile to learn in each lesson.

Syllabus: It is a list of subjects, topic, texts etc included in a course of study. It could be an examination syllabus such as WACE, SSCE, NECO etc.

\section{Five Principles Guiding Syllabus Preparation}

Proceed from

1. Early time to later time (ancient to modern

2. Local to distant (remote)

3. Known to unknown

4. Simple to complex

5. Easy to difficult etc.

Core subjects: These are compulsory subjects which students must register for in exams or do in the class lesson. It also denotes subjects the student must not drop. It helps to classify students into science, art, commerce etc.

School time table: This shows the total time available for instruction in a week. It also shows how this time divided among the various subjects according to their merits. It makes possible the objectives of the syllabus and makes the teacher and class easier, more pleasant and more orderly.

Weekly lesson plan: This involves the extraction of a topic or content to be taught from the syllabus or scheme of work. The preparation includes stating the behavioral objectives, activities, teaching aids and evaluation. Each forms a bleaching in horizontally drawn lines under which the teacher has to apply the details.

Weekly lesson plan helps the teacher to breakdown the topic for the week in advance. It aids preparation of daily lesson note necessary material for the topics are obtained in advance to facilitate teaching. Students can also be asked to bring some of these teaching materials in advance.

\section{CONCLUSION}

Science teaching practice has been recognized as a very important component in the professional education of teachers. Its supervision equally has been a source of concern to many teacher educationists and educators. Science teaching generally refers to something that a science teacher does to influence the learning of science. In a school situation, science teaching involves determination of worthwhile objectives, selection and organization of content and learning experiences, guidance, motivations and evaluation with a view to assuring and enhancing learning. The science teacher may simply impact information that the learners do not possess, or develop a skill, may act the way others may imitate. Science teachers may apply persuasion, spotlighting a particular point to sources of information. In this way, the science teaching involves a variety of activities to be performed by the teacher and the learners. 


\section{References}

[1] Alaku, P.O. (1998). Instructional strategies and its usual aids for teacher's effectiveness. Bichi Journal of Education 2 (1), 114-117

[2] Imarhiagbe K.O (1996). Interactive Approach to the Teaching and learning of Science, Technology and Mathematics. In J.O. Enabowo and J.N. Umeoduagu(eds), Science, Technology and Mathematics (STM) Education in Contemporary Nigeria. Agbor: Kmensno Education Publishers.

[3] Iwuji, V.B.C. (1990). Measurement and Evaluation for Effective Teaching and Learning. Onitsha:Summer Educational Publishers.

[4] Makama,, O.M. (2005) Programme Evaluation in Education. Obosi: Pacific Publishers.

[5] Ohuche, K.O. (1990). Basic Measurement and Evaluation. Onitsha: Africana-Fep Publishers.

[6] Opara, J.A(2011). The Science Education and Student Achievement in Nigerian Environment: Concerns and Tasks Ahead. Middle-East Journal of Scientific Research. Vol.7, No. 6, p.10501055

[7] Opara,J.A(2014). Education and the Enlightened Society. New Delhi: New Delhi Publishers

[8] Opara, J.A and Ejifugha,A.U(2014). "Emerging Approach of Teaching School Science Through Inquiry Method”. Journal of Educational and Social Research, Vol.4, No.7, pp.121

[9] Opara,J.A(2015).State of Education and Globalization. Saarbrucken-Germany:LAP Lambert Academic Publishing

[10] Opara, J.A(2015).Science Education in an Changing Environment. New Delhi: New Delhi Publishers 137

[11] Saidu, S (2007) Functional Curriculum for National Economic Empowerment and Development, Nigeria Journal of Science and Educational Research 1(14)265-269. 